\title{
Throughfall in balsam fir: Some landscape-scale implications in western Newfoundland
}

\author{
by A.R. van Kesteren ${ }^{1}$
}

\begin{abstract}
Throughfall, the process of rainfall passage through a tree canopy to the forest floor, is a critical hydrological cycle component affecting in situ soil to watershed-scale processes. The process has been widely studied at plot scales, but integrative forest stand and landscape studies are rare. A landscape-scale study was undertaken to investigate balsam fir (Abies balsamea (L.) Mill.) forest cover, slope aspect, and interaction of these factors on throughfall receipt in western Newfoundland. ANOVA analyses found balsam fir forest cover to be the predominant variable influencing throughfall over the summer-to-autumn season. Slope aspect and interactions of forest cover and aspect were not significant. Some landscape-scale implications are discussed.
\end{abstract}

Key words: balsam fir, forest hydrology, landscape scale, slope aspect, throughfall

\section{RÉSUMÉ}

Le ruissellement végétal, le cheminement des précipitations retenues par le couvert forestier vers le sol, constitue un élément important du cycle hydrologique qui affecte directement les processus se déroulant dans le sol et le bassin versant. Le processus a été étudié plusieurs fois au niveau des parcelles, mais les études complètes au niveau du peuplement forestier et de l'écosystème sont rares. Une étude de l'écosystème a été entreprise dans le but d'étudier le couvert forestier du sapin baumier (Abies balsamea (L.) Mill.), l'aspect des pentes et les interactions entre ces facteurs sur le résultat du ruissellement végétal dans l'ouest de Terre-Neuve. Des analyses ANOVA ont révélé que le couvert forestier du sapin baumier constitue la variable prédominante du ruissellement végétal de l'été jusqu'à l'automne. L’aspect des pentes et les interactions entre le couvert forestier et les pentes ne se sont pas révélés être des facteurs significatifs. Quelques-unes des implications écosystémiques font l'objet de discussions.

Mots clés : sapin baumier, hydrologie forestière, échelle écosystémique, aspect des pentes, ruissellement végétal

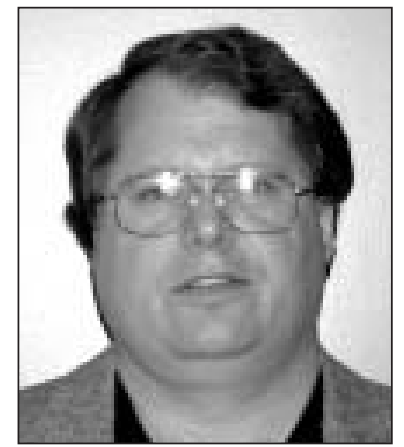

A.R. van Kesteren

\section{Introduction}

Forests are exceedingly complex, exhibiting a broad range of processes in the spatial and temporal domains. Consequently, forest management requires robust ecological knowledge tempered by an understanding that ecosystem complexity cannot always be pragmatically represented by singular scales (Levin 1992). Complex ecosystem dynamics and feedback mechanisms can generate differing patterns detectable through observation and measurement. However, extrapolation between plot, stand, and landscape levels may be hindered by incomplete understanding of scale invariance or dependencies of observed patterns. Therefore, scaling should not be assumed as simple data aggregation or disaggregation operations (Gardner 1998, Lovell et al. 2002). Additionally, fine-scale stand processes have had considerable research focus, but application to enhance broader landscape-scale forest management is less developed (Lertzman and Fall 1998).
The importance of addressing freshwater resource issues through adequate research and policy direction, and the need for a national freshwater strategy, has been stated strongly (Schindler 2001). In Canada, there is a commitment to advance sustainable forest ecosystem management, of which freshwater resources are a critical component (Natural Resources Canada 2004). However, measurement and monitoring tools are required to support this commitment and provide a means of progress reporting and linkage across local, regional, and national levels (Hall 2000). An increased understanding of hydrological-scale interrelationships is also imperative (McCulloch and Robinson 1993, Blöschl and Sivapalan 1995) and requisite for freshwater water conservation in Canadian forested environments (Buttle et al. 2000, Hall 2000).

Throughfall, the process of rainfall passage through a tree canopy to the forest floor, is a predominant hydrological cycle component affecting in situ soil to watershed-scale processes. It may be influenced by forest canopy species and structure, ambient rainfall and meteorological conditions, topographic factors including slope and aspect, and interaction of these factors at different scales of space and time (Crockford and Richardson 2000). Many observational investigations, for differing species, have been undertaken at a plot level to quantify

${ }^{1}$ Forest Research Officer, Natural Resources Canada, Canadian Forest Service - Atlantic Forestry Centre, P.O. Box 960, Corner Brook, Newfoundland A2H 6J3. E-mail: rvankest@nrcan.gc.ca. 


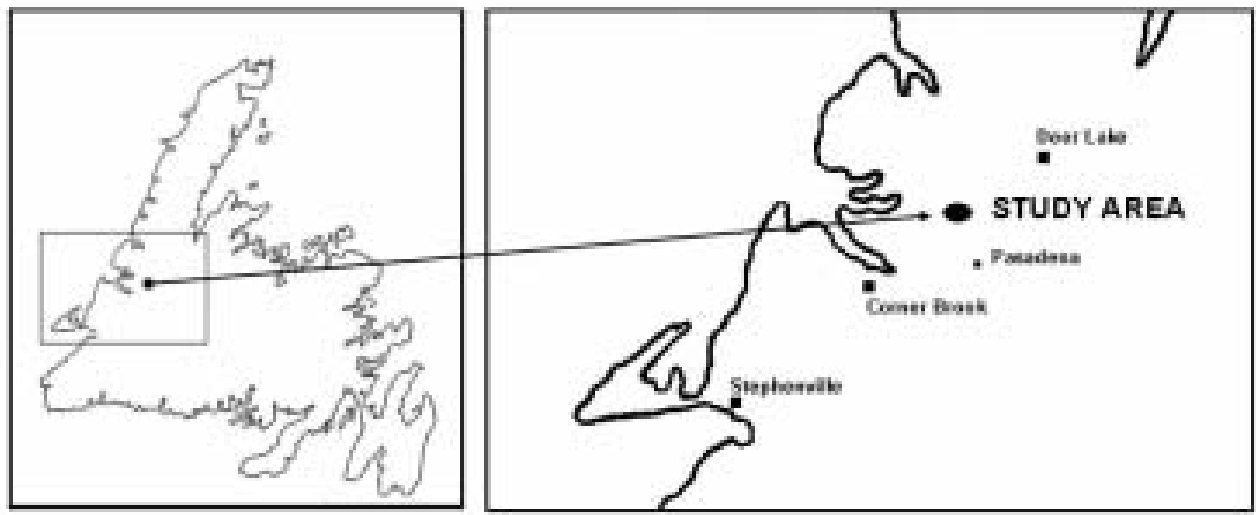

Fig. 1. Regional setting and study area location on the island of Newfoundland.

physical and chemical properties of throughfall. However, integrative landscape-scale studies with explicit experimental design and hypothesis testing are rare. This despite an increasing awareness of ecological interconnectedness of hydrological cycle components (Slaymaker 2000), and the need for statistically rigorous studies to aid development of data scaling methods (Hall 2000).

Previous stand-level studies for balsam fir (Abies balsamea (L.) Mill.) have reported throughfall results from New Hampshire (Olson et al. 1981) and Nova Scotia (Freedman and Prager 1986). In New Brunswick, throughfall prediction equations for balsam fir have been published (Mahendrappa and Kingston 1982, Mahendrappa 1990). However, potential landscape-scale influences on the throughfall process for balsam fir forest were not explicitly investigated in these previous studies. In western Newfoundland, balsam fir predominates in the regional forest types, with a wide distribution over a complex topography of hilly to mountainous terrain (Damman 1967). The species has not been studied in relation to important forest hydrological processes of the region. The general objective of this work is to broaden landscape-scale knowledge of throughfall processes in support of the development of sustainable forest management practices. Specifically, this study investigates throughfall processes at a landscape scale using a replicated field experiment in a representative terrain of western Newfoundland. Hypotheses of no significant differences in throughfall and incident rainfall for cover type, slope aspect, interaction of cover type and aspect, and within-cell replication were tested.

\section{Study Area Description and Rainfall Climatology}

The experiment was undertaken in western Newfoundland (Fig. 1) within Section B28b of the boreal zone (Rowe 1972). Upland balsam fir forests are predominantly dispersed over a rugged and hilly topography at an elevational range of 300 to $600 \mathrm{~m}$ (Damman 1983). Cover type classification was a balsam fir stand aged 41-60 years, dominant height class of 6.6-9.5 m, crown density of 51-75\%, and 9700 live stems/ha. Species densities were $95.1 \%$ for balsam fir and 3.3\%, 0.9\% and $0.7 \%$, black spruce (Picea mariana (Mill.) BSP), white spruce (Picea glauca (Moench) Voss), and white birch (Betula papyrifera Marsh.), respectively. Geology consists of undivided sedimentary rocks and greenschist (Hibbard 1985) with a morainal veneer over hummocky bedrock (Wells et al. 1972) and gleyed humo-ferric and orthic ferro-humic podzolic soils (Kirby et al. 1992). Local hilly relief within the immediate study area is of the order of tens of meters, with a general southwest to northeast summit trend, and elevations ranging from $380 \mathrm{~m}$ asl to a maximum of $457 \mathrm{~m}$ asl.

Principal summer cyclonic storm tracks affecting western Newfoundland lie across the Gulf of St. Lawrence and through the Strait of Belle Isle (Banfield 1993). Autumnal storm tracks migrate southward, and are increasingly intense with cold front passage. Tracks are under the influence of prevailing upper westerly flows with day-to-day, near-surface wind directions varying with the passage of individual systems. North easterlies and easterlies are significant surface winds during cyclonic precipitation within the region (Brookes 1972). Summer low-pressure systems, originating in the central United States or south-central Canada from conflicting tropical Gulf and modified Pacific air masses, can produce significant rainfall in the study region. Late summer and autumn low-pressure systems, originating as North Atlantic Ocean tropical storms and hurricanes, can bring heavy convective rains. Uplifting of moist air as it reaches coastal regions results in significant orographic precipitation influence for western Newfoundland and autumnal fogs may develop at higher elevations (Banfield 1981, 1983). Inland from the Corner Brook location, increasing elevations and rugged topography can enhance precipitation receipt, whereas the Deer Lake locale can experience rain shadow effects during westerly air flows (Banfield 1981). Mean annual 30 -year normal rainfall at Corner Brook is $849 \mathrm{~mm}$ (Environment Canada 2002) with increasing elevations and rugged topography representative of the study site.

\section{Methods}

Field

A representative area of approximately $1.0 \mathrm{~km}^{2}$, characterized by two contrasting cover types: (i) a logged clearcut suitable for sampling incident rainfall receipt, and (ii) a balsam fir forest suitable for throughfall determination, was chosen. The cover types were stratified by easterly and westerly aspects and summits on original scale 1:12 500 black-and-white aerial photographs through an air photo interpretive and field verification approach (van Kesteren 1992, 1996). A 3-m high 

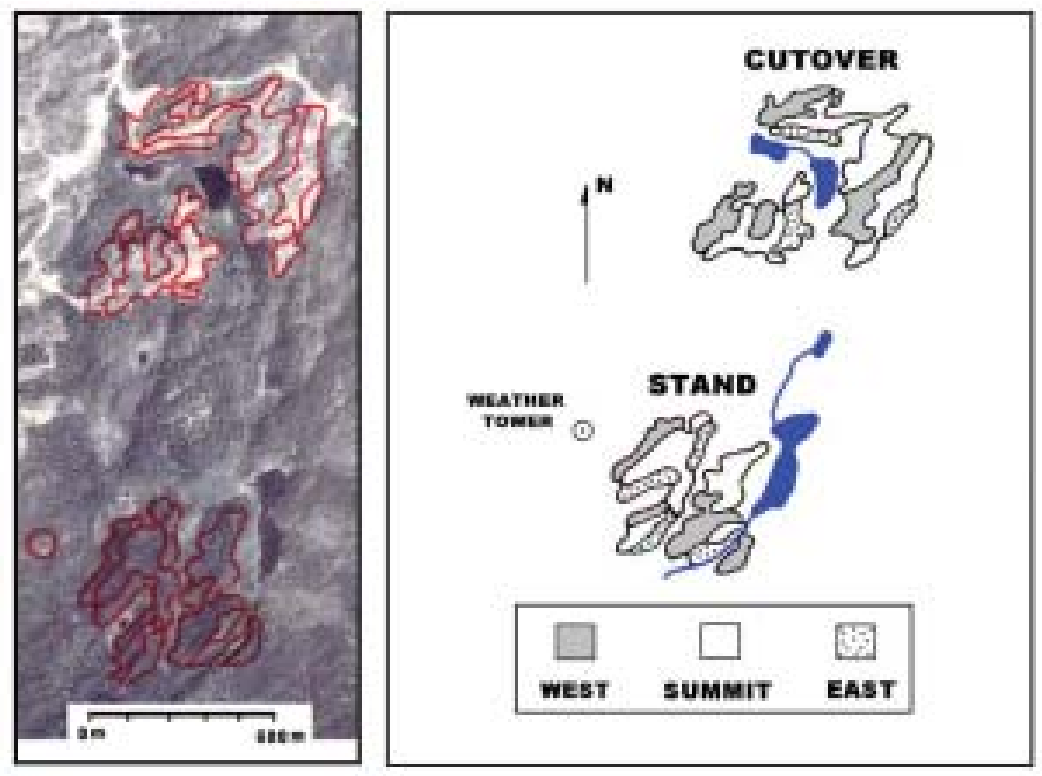

Fig. 2. Air photo delineations (left) and classified field replicates (right) west, summit, and east for cutover and stand cover. Bar scale in meters.

instrumented weather tower and a tipping bucket rain gauge were established on an elevated site, with no tree cover, suitable for unobstructed wind speed, direction and rainfall monitoring (Fig. 2).

A pilot study for sample size estimation was undertaken at the experimental site, applying the method of Lawrence and Fernandez (1993). Gauges were improvised by attaching 9.2$\mathrm{cm}$ diameter funnels to 500 - and $1000-\mathrm{mL}$ capacity nalgene bottles for throughfall and incident rainfall collection, respectively. Performance for three gauges of each improvised type was compared with rainfall catches of three clear-view standard rain gauges having a $10.0-\mathrm{cm}$ diameter in a test with all gauges located on a flat field site with no obstructions. As predetermined by the sample size estimation, gauges were randomly located throughout the slope aspect replicates of the clearcut and balsam fir forest cover types at $30 \mathrm{~cm}$ horizontal height above ground (World Meteorological Organization 1961) and attached to a plot center survey stake. Obstruction on clearcut sites was minimized by removing all vegetation $\geq$ $20 \mathrm{~cm}$ in height or logging residue to a radius of $4 \mathrm{~m}$ from the plot center gauge locations. Gauges were read for forecasted rainfall events on following clear days and after cessation of canopy drip. Two seasons of data were compiled from June 7 to October 7 and from June 18 to September 8 in 1998 and 1999, respectively.

\section{Experimental design and analysis}

Effect of forest cover, slope aspect, and interactions on incident rainfall and throughfall were analyzed by means of a factorial fixed effects, nested analysis of variance (ANOVA) model (Zar 1996). Factor A, forest cover type, had two classified levels or sub-factors (i.e., factor levels, after Zar 1996): (i) a balsam fir clearcut and (ii) a second-growth balsam fir stand of 41-60 years of age. Factor B, slope aspect, had three subfactors: (i) east-facing slopes; (ii) southwest-to-northeast trending summits, and (iii) west-facing slopes. The three aspect sub-factors were field-replicated four times for each forest cover subfactor, and sampled with three randomly located gauges (Fig. 2). Analyses were undertaken for 26 rainfall events grouped in 1998, 13 events grouped in 1999, and all events grouped for 1998 and 1999. Null hypotheses of no significant differences in throughfall and incident rainfall for cover type, slope aspect, interaction of cover type and aspect, and within-cell replication were tested with a rejection $p$ value of 0.05 . Analysis was undertaken using the generalized linear model function of Systat 7.01 (SPSS Inc. 1997).

\section{Results}

Sample size determination and rainfall events

A correlation coefficient of $r=0.99, p<$ 0.001 was achieved between the improvised funnel gauges and standard rain gauges, indicating no significant performance differences. A pilot study recorded six events in the summer of 1997 using six funnel gauges each for cutover (incident rainfall) and stand (throughfall) at the experimental field site. A sample size estimation of 36 cutover and 36 stand gauges was computed at $90 \%$ confidence with an allowable standard error of $<12.5 \%$. Similar estimates were noted in the literature (Czarnowski and Olszewski 1970, Kimmins 1973, Kostelnik et al. 1989, Puckett 1991, Lawrence and Fernandez 1993). The 72 gauges were apportioned by the experimental sub-factors and established at fixed random field locations.

Table 1 summarizes rainfall event characteristics for 1998, 1999, and 1998 and 1999 combined.

Total incident rainfall for the 1998 summer-to-autumn sampling period was $575.2 \mathrm{~mm}$, compared with $367.3 \mathrm{~mm}$ for the 1999 summer sampling. A smaller number of events in 1999 contrasted to 1998 resulted from a reduced sampling period. Additionally, 1999 had a reduced frequency in smaller size events of $<10 \mathrm{~mm}$ related to drier synoptic meteorological conditions for that summer season. Prevalent in the size class distributions is a reduced frequency of events exceeding $50 \mathrm{~mm}$, resulting in an expected pattern of positive skew for short precipitation records (Barry and Chorley 1982). High standard deviations of mean rainfall are related to the wide range of event sizes, for both years. The combination of data for both years, however, considerably reduces the higher variability of 1999, observable in comparison of the event size classes percent frequencies.

\section{Data analysis and description}

Cell variances, normality, and related probability levels were examined for 1998, 1999, and $1998+1999$. All cell variance ratios were $\leq 1.6$, whereas most W statistics (Shapiro and Wilk 1965 ) exceeded 0.8 with a $p$ value range of $0.72 \leq p \leq 0.81$. ANOVA is well accepted, with cell variance ratios 10:1 or smaller (Tabachnick and Fidell 1996), and despite salient departures from normality (Zar 1996). The analysis was undertaken without data transformations, with non-para- 
Table 1. Description of discrete rainfall events for 1998 , 1999 , and $1998+1999$. $N$ is the number of discrete events. Mean, standard deviation (SD), and range of events are in millimetres. Rainfall event sizes classes (in $\mathrm{m}$ ) are characterized by absolute numbers and percent frequencies of events, in parentheses. Rainfall event data were acquired by an on-site tipping bucket (Texas Electronics) rain gauge of 0.1 $\mathrm{mm}$ resolution.

\begin{tabular}{lccc}
\hline Year & 1998 & 1999 & $1998+1999$ \\
\hline $\mathrm{N}$ & 26 & 13 & 39 \\
Mean & 21.1 & 24.4 & 22.9 \\
SD & 19.2 & 25.4 & 21.1 \\
Range & $0.3-67.3$ & $4.0-95.7$ & $0.3-95.7$ \\
Size Class & & & \\
$\leq 10$ & $11(42.3 \%)$ & $4(30.8 \%)$ & $15(38.5 \%)$ \\
$>10 \leq 25$ & $6(23.1 \%)$ & $4(30.8 \%)$ & $10(25.6 \%)$ \\
$>25 \leq 50$ & $6(23.1 \%)$ & $3(23.1 \%)$ & $9(23.1 \%)$ \\
$>50$ & $3(11.5 \%)$ & $2(15.3 \%)$ & $5(12.8 \%)$ \\
\hline
\end{tabular}

metric Mann Whitney U tests (MW) and Kruskall-Wallis (KW) for the cover and aspect factors, respectively, performed as adjunct analyses. The forest cover type sub-factors of cutover (incident rainfall) compared with stand (throughfall) for 1998, 1999, and $1998+1999$ resulted in null hypothesis rejection at $p \leq 0.001$ (Fig. 3 ), with $\mathrm{F}_{1,19}=14.7,14.6$, and 17.7, respectively. Non-parametric Mann Whitney $U$ tests (MW) for the cover factor also resulted in rejection at $\mathrm{p}<$ 0.001. For the aspect factor, ANOVA and Kruskall-Wallis (KW) $p$ values of $\leq 0.10$ for years 1999 and $1998+1999$ warrant consideration for potential physical process influences on incident rainfall and throughfall processes. Forest type and aspect interaction and within cell analysis were all non-significant with $p>0.2$.

Table 2 presents a summary and comparison of sub-factors and cell data by years 1998, 1999, and 1998 and 1999 combined. All standard errors (SEM) are less than 10\% of mean values, but are notably greater for 1999 compared with 1998 and the two years combined. Standard errors are also consistently higher associated with the stand level and stand cells but with no apparent trend. An east-to-west gradient of increasing magnitudes of mean values and 95\% confidence intervals in aspect factor levels is salient. In all cases, the west aspect level is greater than the summit, which is greater than the east. Representing the west aspect level as $100 \%$ and computing percentages as an average of the upper and lower confidence interval limits, the east-summit-west gradients are 95\%-95.5\%-100\%, 88\%-90\%-100\%, and $92.5 \%-93.7 \%-100 \%$ for 1998,1999 , and $1998+1999$, respectively (Fig. 4). The same trend is apparent at the cell level, more particularly for the stand cells (SE, SS, and SW) vs. the cutover cells (CE, CS, and CW), and is strongest for 1999. Despite statistical non-significance, the consistency of this trend could relate to potential physical dynamics influencing the throughfall process.

\section{Discussion}

There is strong consensus from theory and empirical study that throughfall derived from incident rainfalls is of reduced magnitude resulting from canopy interception (Leonard

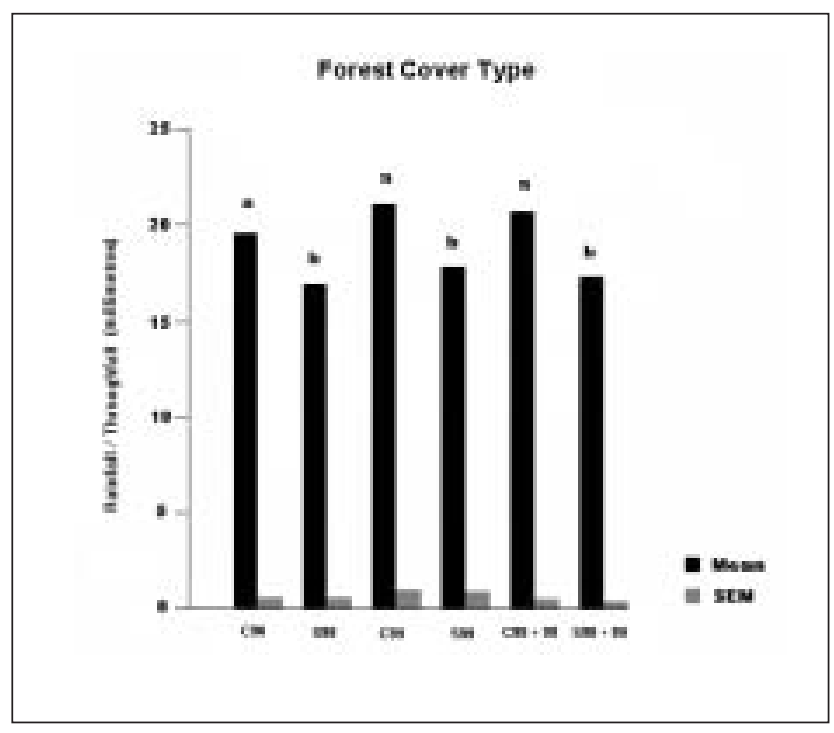

Fig. 3. Significantly different intra-year mean rainfall and throughfall for forest cover-type sub-factors cutover (C) and stand (S) for years 1998 (98), 1999 (99) and $1998+1999$ (98 + 99). Lower case $a$ and $b$ indicate significance at $p \leq 0.001$. SEM is standard error of the mean.

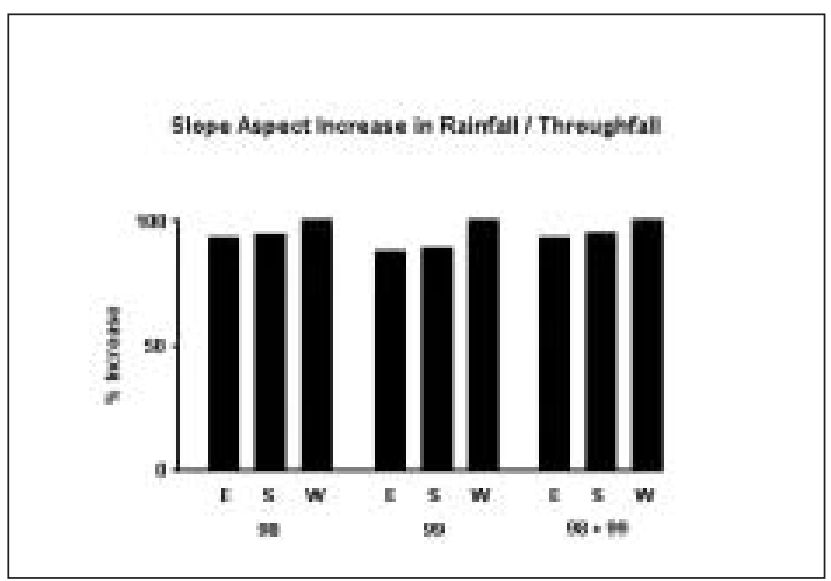

Fig. 4. Percentage increase of rainfall and throughfall on East (E), Summit (S), and West (W) slope aspects for 1998 (98), 1999 (99) and 1998 and 1999 (98 + 99) combined.

1967, Parker 1983). Additionally, throughfall variability possesses a spatial component at tree (plot)- and stand-scale resolutions extending to a continuum of the broader landscape scale of forest stand types (Thimonier 1998). The strong rejection of the null hypothesis (cutover vs. stand) for 1998, 1999 , and these years combined, supports second-growth balsam fir cover in western Newfoundland being a dominant reducer of incident rainfall. Additionally, averaged plot-scale incident rainfall and throughfall measurements over a wide range of rainfall events translate into a statistically significant difference supporting landscape-scale stability of the throughfall process on a seasonal basis. Forest stands are distributed over terrain with varying topography (landscape heterogeneity) and interact with ambient meteorological conditions (atmospheric forcing variability). Earlier work recognized this potential, recommending the use of delin- 
Table 2. Data description by sub-factors for years 1998,1999 , and $1998+1999$. $\mathbf{N}$ is the number of individual funnel gauge measurements, with missing measurements from wild animal disturbances indicated in parentheses, Mean in millimetres, $\mathrm{Cl}$ ( $L-U$ ) - 95\% confidence interval ( $L$ - lower and $U$ - upper limits) for mean and SEM - standard error of mean. CW, CS, CE, SW, SS, and SE are cells: cutover west, cutover summit, cutover east, stand west, stand summit and stand east. Lower-case letters ${ }^{a}$ and $^{b}$ indicate significantly different intra-year means at $p \leq 0.001$.

\begin{tabular}{|c|c|c|c|c|c|}
\hline Levels & Year & $\mathrm{N}$ & Mean & $\mathrm{CI}(\mathrm{L}-\mathrm{U})$ & SEM \\
\hline Cut & 98 & 936 & $19.8^{a}$ & $18.8-20.9$ & 0.55 \\
\hline Stand & 98 & $932(4)$ & $17.1^{\mathrm{b}}$ & $16.0-18.1$ & 0.54 \\
\hline West & 98 & $621(3)$ & 19.0 & $17.7-20.4$ & 0.68 \\
\hline Summit & 98 & $623(1)$ & 18.2 & $16.9-19.5$ & 0.66 \\
\hline East & 98 & 624 & 18.1 & $16.8-19.4$ & 0.67 \\
\hline CW & 98 & 312 & 20.2 & $18.3-22.1$ & 0.97 \\
\hline CS & 98 & 312 & 19.6 & $17.7-21.4$ & 0.92 \\
\hline $\mathrm{CE}$ & 98 & 312 & 19.8 & $17.9-21.7$ & 0.97 \\
\hline SW & 98 & $309(3)$ & 17.9 & $16.1-19.9$ & 0.95 \\
\hline SS & 98 & $311(1)$ & 16.9 & $15.0-18.7$ & 0.93 \\
\hline SE & 98 & 312 & 16.4 & $14.6-18.2$ & 0.92 \\
\hline Cut & 99 & 468 & $22.0^{\mathrm{a}}$ & $20.0-24.0$ & 1.03 \\
\hline Stand & 99 & $461(7)$ & $17.9^{b}$ & $16.1-19.8$ & 0.96 \\
\hline West & 99 & $311(1)$ & 21.6 & $19.0-24.2$ & 1.31 \\
\hline Summit & 99 & $309(3)$ & 19.4 & $17.1-21.7$ & 1.17 \\
\hline East & 99 & $309(3)$ & 19.0 & $16.7-21.3$ & 1.18 \\
\hline CW & 99 & 156 & 22.5 & $18.9-26.1$ & 1.83 \\
\hline CS & 99 & 156 & 21.9 & $18.4-25.5$ & 1.79 \\
\hline $\mathrm{CE}$ & 99 & 156 & 21.6 & $18.1-25.0$ & 1.75 \\
\hline SW & 99 & $155(1)$ & 20.7 & $17.0-24.4$ & 1.89 \\
\hline SS & 99 & $153(3)$ & 16.8 & $13.8-19.7$ & 1.50 \\
\hline SE & 99 & $153(3)$ & 16.3 & $13.3-19.4$ & 1.55 \\
\hline Cut & $98+99$ & 1404 & $20.6^{\mathrm{a}}$ & $19.6-21.6$ & 0.50 \\
\hline Stand & $98+99$ & 1393(11) & $17.3^{\mathrm{b}}$ & $16.4-18.3$ & 0.48 \\
\hline West & $98+99$ & $932(4)$ & 19.9 & $18.7-21.1$ & 0.81 \\
\hline Summit & $98+99$ & $932(4)$ & 18.6 & $17.5-19.8$ & 0.59 \\
\hline East & $98+99$ & $933(3)$ & 18.4 & $17.2-19.6$ & 0.59 \\
\hline $\mathrm{CW}$ & $98+99$ & 468 & 20.9 & $19.2-22.7$ & 0.89 \\
\hline CS & $98+99$ & 468 & 20.4 & $18.7-22.0$ & 0.86 \\
\hline $\mathrm{CE}$ & $98+99$ & 468 & 20.4 & $18.7-22.1$ & 0.87 \\
\hline SW & $98+99$ & $464(4)$ & 18.9 & $17.1-20.6$ & 0.89 \\
\hline SS & $98+99$ & $464(4)$ & 16.8 & $15.3-18.4$ & 0.80 \\
\hline SE & $98+99$ & $465(3)$ & 16.4 & $14.8-17.9$ & 0.80 \\
\hline
\end{tabular}

eated topographic facets of uniform slope, aspect, and elevational zonation for rainfall monitoring in forested watersheds (Corbett 1967). In this study, slope aspect alone, the interaction between it and forest cover, as well as within-cell variability were found to be statistically non-significant for throughfall and incident rainfall receipt, supporting independence of these experimental factors. Thus, simple random sampling, without aspect stratification, could suffice for annual and longer-term averaged estimation of throughfall or incident rainfall on this terrain type, which is representative of western Newfoundland upland balsam fir forests. However, averaged estimation of incident rainfall and throughfall processes above the range of hill sizes and relief structures characteristic of the present study area may require stratification.

Although seasonal statistical significance for aspect stratification was not detected, the results note a consistent east-towest trend of incident rainfall and throughfall magnitude increases associated with 39 discrete events sampled over 1998 and 1999. The east-to-west trend of increases for individual events grouped may have biological or forest hydrological significance. During 1998, rainfall events were accompanied by winds between the northeast to southeast, which may 
have resulted in a throughfall gradient from decreasing rainfall receipt on upwind hill slopes and compensatory leewardside increases. Such physical processes are known to occur in forest environments and hilly terrain (Lee 1978, Oke 1987). However, further event-based analysis would be required to investigate this trend and elucidate potential processes.

Stability and variance reduction can result from long-term temporal averaging of hydrological data, although it may not uniquely enable robust, short-term, hydrological response prediction (Milly and Eagleson 1987). Temporal averaging effects with variability reductions for larger sampling numbers and longer time frames are evident in the present study (Table 2). However, data measured and averaged at coarse resolutions can restrict detailed inter- and intra-storm analysis of the throughfall process, thus affecting throughfall quantification and prediction (Crockford and Richardson 2000, King and Harrison 1998). Application of throughfall prediction equations (for balsam fir and other species) was concluded to be suitable for watershed-level management and for the estimation of regional weekly and monthly throughfall magnitudes (Mahendrappa and Kingston 1982, Mahendrappa 1990). Although the present study was not long-term, a seasonally averaged, landscape-level stability of throughfall for balsam fir in western Newfoundland provides support for this conclusion.

Spatio-temporal distributions of incident rainfall derive from a hierarchical process-response system linking synoptic, mesoscale, and local meteorological conditions interacting with landscape heterogeneity. Interpretation of differing resolutions of incident rainfall and throughfall will, therefore, depend on the ratio of characteristic synoptic scales to the scale of a study area. Study of synoptic rainfall gradients, for example, requires a suitably large study area, enabling observations of storm passage and interactions with the broader landscape. However, study of potential local terrain influence, at a minimum, requires scales small enough to be contained within the spatio-temporal boundaries of the smallest individual synoptic systems characteristic of a region. The experimental site, encompassing approximately $1.0 \mathrm{~km}^{2}$, minimized scale-dependent process ambiguities as plot-to-plot distances were as fine or less than the resolvable scale of 1- to 10-km diameters for individual rain cells (Sumner 1988). The precipitation climatology of western Newfoundland is strongly influenced by the presence of insular Newfoundland's highest uplands, the Long Range Mountains. Resultant synoptic-scale, orographic rainfall gradients from coastal to adjacent upland locations of western Newfoundland can thus occur as moist air crosses the study region (Banfield 1983). A large study area would have resulted in a data set generated from a mixing of local processes and systematic variations associated with synoptic rainfall gradient effects. Such an inter-scale mixing could result in non-trivial complexities and erroneous interpretation of the experimental results.

Although the degree of field heterogeneity accepted is a subjective judgment and does not invalidate the robustness of the experiment design (Hurlbert 1984), incorporation of spatial heterogeneity could help reduce systematic data errors and bias, thus strengthening sensitivity of the analysis and the interpretation of statistical results (Dutilleul 1993). This is particularly so in scaling studies, where landscape heterogeneity can be characterized by distinct structures of form and process (Blöschl and Sivapalan 1995). Thus, forest hydro- logical studies require geographic considerations of topological and areal relationships at plot, stand, and local landscape scales with careful consideration of field layouts and the relationships to physical processes that generate the experimental data. This investigation at the local terrain scale is regionally representative of landscape heterogeneity, and could enhance extrapolation of findings to a broader level of western Newfoundland upland balsam fir forests. Consequently, examination of both stand and topographic heterogeneities may provide useful integrating frameworks for understanding landscape spatial and temporal scale influences on incident rainfall and throughfall partitioning.

\section{Conclusions}

Seasonal or longer-term data averaging supports stability and independence of incident rainfall and throughfall processes relative to local landscape heterogeneity for the specific terrain of this study. However, evidence for landscape dependence of throughfall flux magnitudes for individual events is also presented. The use of seasonal throughfall averages in forest hydrological applications should, therefore, consider meteorological event variability and potential terrain interactions. A first approximation of a landscape-scale areal limit for the potential separation of local topographic from regional synoptic gradient effects has been demonstrated. Increased understanding of stand- and landscape-level forest hydrological processes for western Newfoundland upland balsam fir forests has been achieved.

\section{Acknowledgments}

The author thanks P. Hazlett, M.K. Mahendrappa, and B.A. Roberts of the Canadian Forest Service for their useful review comments.

\section{References}

Banfield, C.E. 1981. The climatic environment of Newfoundland. In J. Brown Macpherson and A.G. Macpherson (eds.). The Natural Environment of Newfoundland: Past and Present. pp. 82-153. Memorial University of Newfoundland, Department of Geography, St. John's, NF.

Banfield, C.E. 1983. Climate. In G.R. South (ed.). Biogeography and Ecology of the Island of Newfoundland. pp. 37-106. Dr. W. Junk Publishers, The Hague, Netherlands.

Banfield, C.E. 1993. Newfoundland climate: past and present. In A. Robertson, S. Porter and G. Brodie (eds.). Climate and Weather of Newfoundland and Labrador. pp. 13-32. Creative Printers, St. John's, NF.

Barry, R.G. and R.J. Chorley. 1982. Atmosphere, Weather and Climate. Methuen and Co. Ltd., London, UK. 425 p.

Blöschl, G. and M. Sivapalan. 1995. Scale issues in hydrological modelling: a review. Hydrological Processes 9: 251-290.

Brookes, I. 1972. The physical geography of the Atlantic provinces. In A.G. Macpherson (ed.). The Atlantic Provinces: Studies in Canadian Geography. pp. 1-45. University of Toronto Press, Toronto, ON.

Buttle, J.M., I.F. Creed and J.W. Pomeroy. 2000. Advances in Canadian forest hydrology, 1995-1998. Hydrological Processes 14: 1551-1558.

Corbett, E.S. 1967. Measurement and estimation of precipitation on experimental watersheds. In W.E. Sopper and H.W. Lull (eds.). International Symposium on Forest Hydrology. pp. 107-129. Pergamon Press, Oxford, UK.

Crockford, R.H. and D.P. Richardson. 2000. Partitioning of rainfall into throughfall, stemflow and interception: effect of forest type, ground cover and climate. Hydrological Processes 14: 2903-2920. 
Czarnowski, M.S. and J.L. Olszewski. 1970. Number and spacing of rainfall gauges in a deciduous forest stand. Okios 21: 48-51.

Damman, A.W.H. 1967. The forest vegetation of western Newfoundland and site degradation associated with vegetation change. Ph.D. thesis, University of Michigan, Ann Arbor, MI, USA.

Damman, A.W.H. 1983. An ecological subdivision of the island of Newfoundland. In G.R. South (ed.). Biogeography and Ecology of the Island of Newfoundland. pp. 163-206. Dr. W. Junk Publishers, The Hague, Netherlands.

Dutilleul, P. 1993. Spatial heterogeneity and the design of ecological field experiments. Ecology 74(6): 1646-1658.

Environment Canada. 2002. Canadian Climate Normals 19712000. Atmospheric Environment Service. [online]. Available at http://www.climate.weatheroffice.ec.gc.ca/climate_normals/index_e .html.

Freedman, B. and U. Prager. 1986. Ambient bulk deposition, throughfall and stemflow in a variety of forest stands in Nova Scotia. Canadian Journal of Forest Research 16: 854-860.

Gardner, R.H. 1998. Pattern, process and the analysis of spatial scales. In D.L. Peterson and V.T. Parker (eds.). Ecological Scale Theory and Applications. pp. 17-24. Columbia University Press, New York, NY.

Hall, J.P. 2000. The issue of scale in the aggregation of data on indicators of Sustainable Forest Management from subnational to national levels. The Forestry Chronicle 76(3): 419-422.

Hibbard, J. 1985. Map 83-106. Geology of the Island of Newfoundland: Preliminary version. Mineral Development Division, Department of Mines and Energy, Government of Newfoundland and Labrador, St. John's, NF.

Hurlbert, S.H. 1984. Pseudoreplication and the design of ecological field experiments. Ecological Monographs 54(2): 187-211.

Kimmins, J.P. 1973. Some statistical aspects of sampling throughfall precipitation in nutrient cycling studies in British Columbian coastal forests. Ecology 54(5): 1008-1019.

King, B.P. and S.J. Harrison. 1998. Throughfall patterns under an isolated oak tree. Weather 53(4): 111-121.

Kirby, G., K. Guthrie and F. Hender. 1992. Soils of the Sandy Lake-Bay of Islands area, western Newfoundland. Report No. 11. Newfoundland Soil Survey, Soil and Land Management Division, Department of Forestry and Agriculture, St. John's NF.

Kostelnik, K.M, J.A. Lynch, J.W. Grimm and E.S. Corbett 1989. Sample size requirements for estimation of throughfall chemistry beneath a mixed hardwood forest. Journal of Environmental Quality 18: 274-280.

Lawrence, G.B. and I.J. Fernandez. 1993. A reassessment of areal variability of throughfall deposition measurements. Ecological Applications 3(3): 473-480.

Lee, R. 1978. Forest Microclimatology. Columbia University Press, New York, NY. 276 p.

Leonard, R.E. 1967. Mathematical theory of interception. In W.E. Sopper and H.W. Lull (eds.). International Symposium on Forest Hydrology. pp. 131-136. Pergamon Press, Oxford, UK.

Lertzman, K. and J. Fall. 1998. From forest stands to landscapes: spatial scales and the role of disturbances. In D.L. Peterson and V.T. Parker (eds.). Ecological Scale Theory and Applications. pp. 339-367. Columbia University Press, New York, NY.

Levin, S.A. 1992. The problem of pattern and scale in ecology. Ecology 73(6): 1943-1967.

Lovell, C., A. Mandondo and P. Moriarty. 2002. The question of scale in integrated resource management. Conservation Ecology 5(2): 25. [online]. Available from http://www.consecol.org/vol5/ iss $2 / \operatorname{art} 25$.

Mahendrappa, M.K. 1990. Partitioning of rainwater and chemicals into throughfall and stemflow in different forest stands. Forest Ecology and Management 30: 65-72.
Mahendrappa, M.K. and D.G.O. Kingston. 1982. Prediction of throughfall under different forest stands. Canadian Journal of Forest Research12: 474-481.

McCulloch, J S.G. and M. Robinson. 1993. History of forest hydrology. Journal of Hydrology 150: 189-216.

Milly, P.C.D. and P.S. Eagleson. 1987. Effects of spatial variability on annual average water balance. Water Resource Research 23(11): 2135-2143.

Natural Resources Canada. 2004. Sustainable Development Strategy. Moving Forward. Natural Resources Canada, Ottawa, ON. [online]. Available from http://www.nrcan-rncan.gc.ca/sd-dd/ index_e.html.

Oke, T.R. 1987. Boundary Layer Climates. Methuen and Company Ltd., London, UK. 450 p.

Olson, R.K., W.A. Reiners, C.S. Cronan and G.E. Lang. 1981. The chemistry and flux of throughfall and stemflow in subalpine balsam fir forests. Holarctic Ecology 4: 291-300.

Parker, G.G. 1983. Throughfall and stemflow in the forest nutrient cycle. Advances in Ecological Research 13: 58-135.

Puckett, L.J. 1991. Spatial variability and collector requirements for sampling throughfall volume and chemistry under a mixed-hardwood canopy. Canadian Journal of Forest Research 21: 1581-1588.

Rowe, J.S. 1972. Forest Regions of Canada. Department of the Environment, Canadian Forest Service, Ottawa, ON. Publication No. 1300.172 p.

Schindler, D.W. 2001. The cumulative effects of climate warming and other human stresses on Canadian freshwaters in the new millennium. Canadian Journal of Fisheries and Aquatic Science 58: $18-29$.

Slaymaker, O. 2000. Research developments in the hydrological sciences in Canada (1995-1998): surface water - quantity, quality and ecology. Hydrological Processes 14: 1539-1550.

Shapiro, S.S. and M.B. Wilk. 1965. An analysis of variance test for normality. Biometrika 52: 591-611.

Sumner, G. 1988. Precipitation: Process and Analysis. John Wiley and Sons, Chichester, UK.

$472 \mathrm{p}$.

SPSS Inc. 1997. Systat 7.0 for Windows. SPSS Inc. Chicago, IL.

Tabachnick , B.G. and L.S. Fidell. 1996. Using Multivariate Statistics. Harper Collins College Publishers, New York, NY. 880 p.

Thimonier, A. 1998. Measurement of atmospheric deposition under forest canopies: some recommendations for equipment and sampling design. Environmental Monitoring and Assessment 52: 353-387.

van Kesteren, A.R. 1992. Air photo interpretation of Damman forest types on calcareous terrain in western Newfoundland. Forestry Canada, Newfoundland Forestry Centre, St. John's, NF, Info. Rep. N$\mathrm{X}-286.18 \mathrm{p}$.

van Kesteren, A.R. 1996. Forest type occurrence on a calcareous terrain of western Newfoundland. The Forestry Chronicle 72(2): 185-192.

Wells, R.E., J.P. Bouzane and B.A. Roberts. 1972. Reconnaissance land classification of the Corner Brook area, Newfoundland. Pilot project of the National Committee on Forest Land. Environment Canada, Canadian Forest Service - Newfoundland Forest Research Centre, St. John's, NF. Info Rep. N-X-83. 123 p + map.

Zar, J.H. 1996. Biostatistical Analysis. Prentice Hall, Upper Saddle River, NJ. 662 p.

World Meteorological Organization. 1961. Guide to Meteorological Instrument and Observing Practices. WMO - No. 8. TP. 3. Geneva, Switzerland. 